\title{
Learning proteins in the context of molecular gastronomy through higher-order thinking as an activity of fluffy meringue
}

\section{Anna-Sofia Vilhunen}

Unit of Chemistry Teacher Education, Department of Chemistry, University of Helsinki, Finland • annasofia.vilhunen@gmail.com

\section{Maija Aksela}

Unit of Chemistry Teacher Education, Department of Chemistry, University of Helsinki, Finland • maija.aksela@helsinki.fi

\section{Anu Hopia}

Functional Foods Forum, University of Turku, Finland • anu.hopia@gmail.com

\begin{abstract}
This article discusses how to study protein chemistry meaningfully in the context of molecular gastronomy by supporting higher-order thinking skills. The instruction also includes several myths that the students can reflect on. Inquiry-based work is performed in the style of the Top Chef competition: the objective is to prepare the lightest and fluffiest meringue possible. The students act as so called investigating chemistry cooks. The instructions are suitable for secondary school and upper secondary school for studying chemistry of proteins, or for unifying chemistry and home economics in teaching.
\end{abstract}

\section{Introduction}

The aim of the activity is to study the chemistry of proteins meaningfully by exercising higher-order thinking skills as much as possible (e.g. Aksela, Tikkanen \& Kärnä, 2012). The study project has three stages: 1) preparation stage on class, 2) home assignment and 3) production stage on class. The work is performed according to inquiry-based learning in chemistry (e.g. J untunen, 2011). The activity includes the following stages: 1) preparing questions, 2) planning the work, 3) gathering data (exploring the theory, experimenting) and analysing and assessing it, 4) making conclusions and 5) presenting the findings (Vilhunen, 2012). Small groups, two people for example, are well suited for the exercise. The objective of the Top Chef competition is to prepare in groups a meringue with perfect taste and texture.

\section{Recipe for Italian meringue}

Ingredients:

- 5 egg whites

- 250 g sugar

- $0,6 \mathrm{dl}$ water

Method:

- Choose a clean bowl. 
- Separate the whites carefully from the yolk and avoid breaking the yolk.

- Whip the whites into stiff peaks with a whisk or a mixer.

- Measure the sugar and water in a bowl and heat until the solution's temperature is at $118^{\circ} \mathrm{C}$.

- Add the sugar-water solution so that it runs slowly down the inner surface of the bowl into the stiff foam.

- Stir the mass slowly until it cools down.

- Put small pats of meringue on an oven plate.

- Bake the meringues in an oven at $120^{\circ} \mathrm{C}$ for half an hour.

\section{Pedagogic instruction for meringue activity}

The work can be done in three stages:

1) Preparation stage on class: The students are asked to come up with chemistry-related research questions based on different parts of the meringue recipe. The questions are presented to the teacher at the end. Students can freely use eggs, sugar, mixers, whisks and different kinds of bowls and measuring cups for experimenting.

2) Home assignment: To explore the theory and to link it with the experiments and research questions.

3) Production stage on class: Making the meringues. While the meringues are in the oven the students will write down a presentation on the chemistry of proteins and meringues. The top Chef panel of judges, made up of the teacher and students, taste the ready meringues, assess the group work and pick the winner. The winning group is selected based on the lightness and fluffiness of the meringue and, naturally, the theory behind it.

For the judging process, the students have to come up with different ways to measure the lightness of the meringue. The students have to think on what the criteria for lightness are and how to measure it. The students can use scales and microscopes for assessing the lightness.

\subsection{Coming up with research questions}

Usually the students come up with the following kinds of questions:

- What factors affect the texture of the egg white foam? (fat, whisking method, sugar, temperature)

- What kind of structure does the protein have?

- What kind of different functional groups does the protein contain?

- What happens in the egg white foaming process?

- How can these functional groups affect the structure and reactions of the protein?

- What kind of proteins can be found in an egg? 
The recipe includes many myths on cooking that the students should test and come up with an explanation or an alternative. The myths are presented in a separate part of the instruction so that the students find them easily. It is important for the students to challenge the myths and find factual explanations for them from the material they are given and by experimenting.

The following list has the myths highlighted and explained. Questions about the myths that the students should come up with before starting to experiment are in brackets:

- Choose a clean bowl

- Separate the whites carefully from the yolk and avoid breaking the yolk

(Why should the bowl be clean? How does the yolk affect the egg white foam formation and why?)

Fat affects the formation of egg white foam. Dirty dishes often have fat residue and the egg yolk also contains a significant amount of fat. Fat molecules, like proteins, have hydrophilic and hydrophobic parts, thus they move towards the air bubbles' surface and compete for space with the proteins. Fat acts as a lubricant in the bubbles. The difference between fat molecules and proteins is that the fat molecules do not bond closely with each other and form strengthening networks like proteins do. Therefore the fat molecules only get in the way of protein molecules finding each other.

- Whip the whites into stiff peaks with a whisk or a mixer

Whisking method affects the size of the foam's air bubbles. Air bubbles are bigger when using a whisk and smaller but more numerous when using a mixer.

- Measure the sugar and water in a bowl and heat until the solution's temperature is at $118^{\circ} \mathrm{C}$.

- Add the sugar-water solution so that it runs slowly along the bowl into the stiff foam.

- Stir the mass slowly until it cools down.

Raising the temperature improves coagulation. Protein's coagulation process starts at approximately $60^{\circ} \mathrm{C}$. Because of this, a chafing dish is often used.

Proteins can be denatured as a result of heat, acid, alcohol or mechanic movement. In the denaturation reaction the protein coils lose their three-dimensional structure and the coils open up to open-chain compounds.

\subsection{Planning the work}

In the second stage of the work the students plan how to ascertain the factuality of the myths. The aim is for the students to plan what equipment to use, from where to gather the 
needed information and what kind of experiments to conduct to reach conclusions. At this point the teacher checks each group's work separately and makes sure they have what they need.

\subsection{Gathering the data and experimenting}

In the third stage the students gather the data they need from the internet, coursebooks and through inquiry-based learning. This is an important part of the work. It is especially important for the teacher to make sure that the students understand the theory and not just perform the inquiry-based work. Here the teacher can go through the concept of source criticism and ask the students to assess the reliability of their sources. The teacher can also instruct the students on how and where to find scientific studies and articles.

\subsection{Making conclusions}

The students make their conclusions based on the data they have gathered.

The students revise the original meringue recipe based on the data they have gathered in order to make the lightest and fluffiest meringue possible. Then they prepare the meringues and the group work presentation. The teacher can help in this phase by asking some leading questions if the students appear to be at a loss. However, the idea is to let the students work out the connection between the theory and the phenomenon discovered during inquirybased work without the teacher pointing it out.

\subsection{Presenting the findings}

When the group works are ready it is time move into presentation and communication. Each group presents their work, as a poster presentation for example, after which the teacher together with the students groups together the theory, so that everyone understands what went on. The teacher and the students on class can act as Top Chef judges. The judges must first agree on the criteria for assessment. How to measure the fluffiness or lightness of the meringue? When selecting the winning group it is important to emphasise their understanding of chemistry.

\section{Protein theory}

Proteins consist of amino acids. Amino acid is made up of carboxylic acid functional groups $(-\mathrm{COOH})$ and an amino group with a hydrogen atom $\left(-\mathrm{NH}_{2}\right)$. In addition, amino acid has an alpha carbon with an R-group bonded to it. The R-group is variable and at its simplest can be just hydrogen. $\mathrm{R}$ can also be, for example, hydrocarbon or an aromatic hydrocarbon. The R-group defines the amino acid's features. Amino acids are both hydrophilic and 
hydrophobic; they both attract and repel water. Proteins have hundreds of amino acids bonded with each other in peptide bonds (Figure 1).
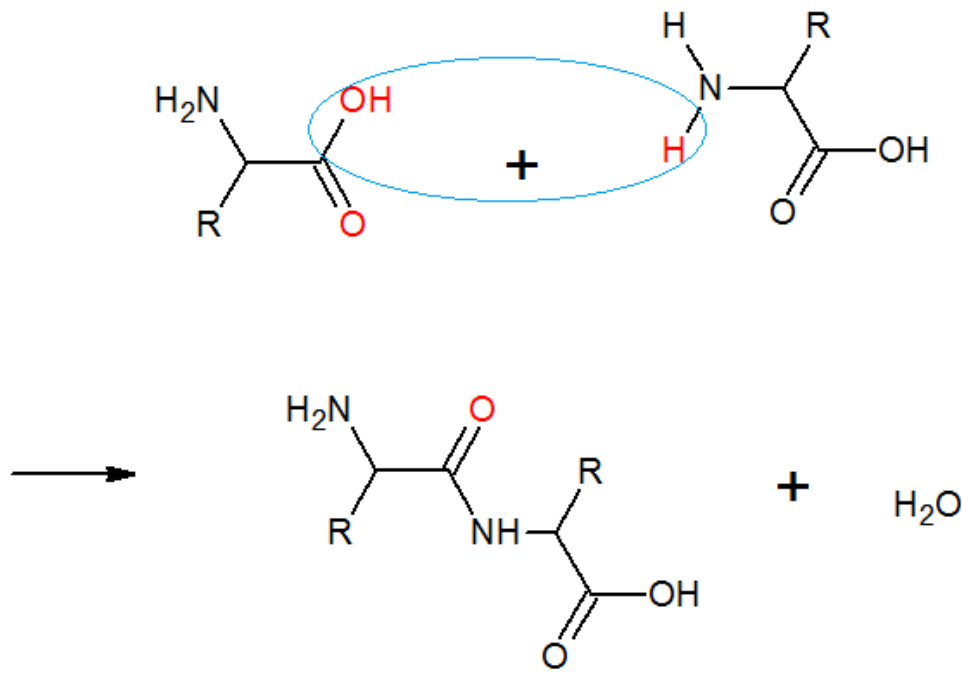

Figure 1. Two amino acid molecules forming a peptide bond.

Protein has four different structures: primary structure, secondary structure, tertiary structure and quaternary structure. The primary structure refers to amino acid linear sequence. The secondary structure refers to a spiralisation or a folding caused by amino acid chain's hydrogen bonds or other interactions within the molecule. The tertiary structure refers to the coil or the spiral folding into a three-dimensional globule with the help of different chemical interactions, such as hydrogen bonds and ionic bonds. The quaternary structure refers to the bonding of two or more amino acid chains in noncovalent bonds.

Proteins can be denatured as a result of heat, acid, alcohol or mechanic movement. In the denaturation reaction the protein coils lose their three-dimensional structure and the coils open up to open-chain compounds.

When the open proteins start reacting to each other they form a network. This results in the coagulation of the protein. Coagulation can be improved by raising the temperature, for example. Denaturation is the first phase in the coagulation process.

An egg white consists of approximately $89 \%$ of water and $10 \%$ of protein. The yolk consists of $48 \%$ of water, $33 \%$ of fat and $17 \%$ of proteins. In addition, an egg contains only small amounts of carbohydrates and various vitamins and minerals.

Proteins, just like amino acids, have both hydrophilic and hydrophobic parts. When whisking an egg white, the opened protein strands gather to the surface of the water and air bubbles; the hydrophilic parts will move towards the water and the hydrophobic parts towards the air bubbles. The end result is a net-like structure where the protein network has bound the water as a thin layer around the air bubbles (Figure 2). 


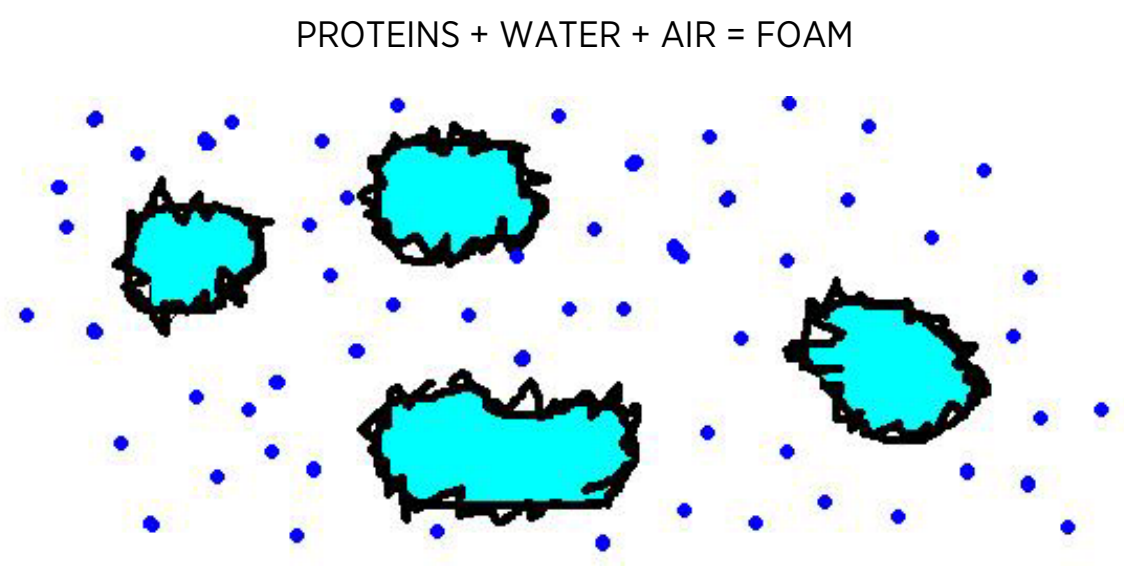

Figure 2. Egg white foam structure. The blue dots represent water, the light blue represent air bubbles enclosed in proteins.

Fat molecules, like proteins, have hydrophilic and hydrophobic parts, thus they move towards the air bubble surfaces and compete for space with the proteins. Fat acts as a lubricant in the bubbles. The difference between fat molecules and proteins is that the fat molecules do not bond closely with each other and form strengthening networks like proteins do. Therefore the fat molecules only get in the way of protein molecules finding each other.

\section{References}

Aksela, M., Tikkanen, G. \& Kärnä, P. (2012). Mielekäs luonnontieteiden opetus: Miten tukea oppilaan ajattelua ja ymmärtämistä? In P. Kärnä, L. Houtsonen \& T. Tähkä (Eds.), Luonnontieteiden opetuksen kehittämishaasteita 2012 (p. 9- 28). Helsinki: The Finnish National Board of Education. Retrieved 10.3.2013 from http:// www.oph.fi/download/145816_Luonnontieteiden_opetuksen_kehittamishaasteita_2012. pdf

J untunen, M. (2011). Kehittämistutkimus: Elinkaariajattelu ja tutkimuksellinen opiskelu kemian opetuksessa. Pro gradu thesis, University of Helsinki, Department of Chemistry, Unit of Chemistry Teacher Education. Retrieved 10.3.2013 from http:// www.helsinki.fi/kemia/ opettaja/ ont/juntunen-m-2011.pdf

Vilhunen, A.-S. (2012). Kehittämistutkimus: Tutkimuksellinen proteiinien opiskelu molekyyligastronomian kontekstissa. Pro gradu thesis, University of Helsinki, Department of Chemistry, Unit of Chemistry Teacher. Retrieved 10.3.2013 from https:/ / helda.helsinki.fi/bitstream/handle/ 10138/34537/kehittam.pdf?sequence=1 